\title{
Inactivation of Human Factor VIII by Activated Protein C Cofactor Activity of Protein S and Protective Effect of von Willebrand Factor
}

\author{
Johannes A. Koedam, Joost C. M. Meijers, Jan J. Sixma, and Bonno N. Bouma \\ Department of Haematology, University Hospital Utrecht, Catharijnesingel 101, 3511 GV Utrecht, The Netherlands
}

\begin{abstract}
Activated protein C (APC) acts as a potent anticoagulant enzyme by inactivating Factor V and Factor VIII. In this study, protein $S$ was shown to increase the inactivation of purified Factor VIII by APC ninefold. The reaction rate was saturated with respect to the concentration of protein $S$ when protein $S$ was present in a 10-fold molar excess over APC. The heavy chain of Factor VIII was cleaved by APC and protein S did not alter the degradation pattern. Factor VIII circulates in a complex with the adhesive protein von Willebrand factor. When purified Factor VIII was recombined with von Willebrand factor, the inactivation of Factor VIII by APC proceeded at a 10-20-fold slower rate as compared with Factor VIII in the absence of von Willebrand factor. Protein $S$ had no effect on the inactivation of the Factor VIII-von Willebrand factor complex by APC. After treatment of this complex with thrombin, however, the actions of APC and protein S towards Factor VIII were completely restored. In hemophilia A plasma, purified Factor VIII associated with endogenous von Willebrand factor, resulting in a complete protection against APC (4 nM). By mixing hemophilic plasma with plasma from a patient with severe von Willebrand's disease, we could vary the amount of von Willebrand factor. $1 \mathrm{U}$ of von Willebrand factor was needed to provide protection of $1 \mathrm{U}$ Factor VIII. Also in plasma from patients with the IIA-type variant of von Willebrand's disease, Factor VIII was protected. In von Willebrand's disease plasma, which was depleted of protein S, APC did not inactivate Factor VIII. These results indicate that protein $\mathrm{S}$ serves as a cofactor in the inactivation of Factor VIII and Factor VIIIa by APC and that von Willebrand factor can regulate the action of these two anticoagulant proteins.
\end{abstract}

\section{Introduction}

Over the past few years, activated protein C (APC) ${ }^{1}$ has become recognized as an important naturally occurring anticoagulant enzyme (1). It exerts its effect by inactivating the cofactors Factor V and Factor VIII (2-7) and by stimulating fibrinolysis $(8,9)$. This anticoagulant pathway is regulated in several ways. Activation of the vitamin $\mathrm{K}$-dependent zymogen protein $\mathrm{C}$ by thrombin is greatly enhanced by thrombomodu-

Address reprint requests to Dr. Koedam, Department of Haematology, University Hospital Utrecht, Catharijnesingel 101, 3511 GV Utrecht, The Netherlands. 1988 .

Received for publication 7 April 1987 and in revised form 31 March

1. Abbreviations used in this paper: APC, activated protein C.

J. Clin. Invest.

(c) The American Society for Clinical Investigation, Inc.

$0021-9738 / 88 / 10 / 1236 / 08 \quad \$ 2.00$

Volume 82, October 1988, 1236-1243 lin, a protein cofactor located on the surface of endothelial cells $(10,11)$. Factor $\mathrm{Va}$ also stimulates the activation of protein C (12). Optimal inactivation of Factor Va by APC is achieved only in the presence of phospholipid, $\mathrm{Ca}^{2+}$, and protein $S(2,3,13)$. Protein $S$ is a vitamin $K$-dependent cofactor of APC. The availability of protein $S$ is diminished by its binding to $\mathrm{C} 4 \mathrm{~b}$-binding protein, a regulatory protein of the complement system $(14,15)$. APC itself is cleared from the circulation by protein $C$ inhibitor, the inhibitor of APC (16). Cell surfaces of platelets (17) and endothelial cells (18) have been implied as being capable of promoting Factor $\mathrm{Va}$ inactivation by assembling the protein S-APC complex. On the other hand, the inactivation reaction is inhibited by Factor Xa $(16,19,20)$. Similarly, Factor IX/IXa was found to protect Factor VIIIa or Factor VIII against inactivation by $\operatorname{APC}(21,22)$. It has also been shown that the thrombin-activated forms of Factor $V$ $(13,19,20)$ and Factor VIII $(5,23)$ are inactivated more rapidly than their precursors. This last finding is of interest because activation of Factor VIII is accompanied by its release from von Willebrand factor (24), a plasma glycoprotein of high molecular weight that mediates the adhesion of platelets to vascular endothelium (25). Lack of von Willebrand factor or increased electrophoretic mobility of the multimeric protein have been correlated with a decreased stability of Factor VIII in plasma (26). These observations have prompted us to investigate the role of von Willebrand factor in regulating the inactivation of Factor VIII/VIIIa by APC. Here we report that in the presence of von Willebrand factor, Factor VIII is protected against inactivation by APC.

\section{Methods}

Materials. Human plasma concentrate containing vitamin K-dependent proteins and Factor VIII concentrates were kindly provided by Dr. J. Over, Central Laboratory of the Netherlands Red Cross Blood Transfusion Service, Amsterdam. Factor VIII concentrates (Hyland Hemofil HT) were also purchased from Travenol Laboratories, Inc. (Munchen, FRG). Sephadex G-25, G-75, and G-200, Sepharose CL-4B, QAE-Sephadex, Blue Sepharose, heparin Sepharose, CNBractivated Sepharose 4B, and mono $S$ and mono $Q$ ion-exchange columns together with the fast protein liquid chromatography system were purchased from Pharmacia Biotechnology (Uppsala, Sweden). Enzymological iodination reagent was obtained from Bio-Rad Laboratories (Richmond, CA). Chromogenic substrates S2238 (H-D-Phe-pipecolyl-Arg-p-nitroaniline) and S2366 (L-pyroGlu-Pro-Arg-p-nitroaniline) and the Coatest Factor VIII assay were from KabiVitrum (Stockholm, Sweden). $\mathrm{Na}^{125} \mathrm{I}$ (sp act $14 \mathrm{mCi} / \mu \mathrm{g}$ iodine) was from Amersham (Buckinghamshire, UK). Centricon 30 ultrafiltration membranes were from Amicon Corp. (Danvers, MA). Cephalin and kaolin were from Boehringer Mannheim (Mannheim, FRG). Rabbit brain thromboplastin was from Dade American (Aguada, Puerto Rico). Factor V-deficient plasma was from Merz+Dade AG (Düdingen, Switzerland). Plasmas deficient in Factor VIII (Factor VIII:C $<0.01 \mathrm{U} / \mathrm{ml}, \mathrm{VWF}: \mathrm{Ag}=1.2 \mathrm{U} / \mathrm{ml}$ ) and von Willebrand factor (Factor VIII:C $<0.01 \mathrm{U} / \mathrm{ml}$, VWF: $\mathrm{Ag}<0.0004 \mathrm{U} / \mathrm{ml}$ ) were from patients of 
our hospital. These plasmas contained undetectable amounts of Factor VIII antigen (23). Protein S antigen in these plasmas was 89 and $92 \%$, respectively. Factor $\mathrm{V}$ concentration in these plasmas was 100 and $72 \%$, respectively. Patients with type IIA von Willebrand's disease were diagnosed by means of a decreased ristocetin cofactor activity (27) and lack of high molecular weight multimers (28). Peroxidase-conjugated rabbit anti-von Willebrand factor antibody was from Dako Corp. (Copenhagen, Denmark). Antibodies against von Willebrand factor, protein $\mathrm{C}$, and protein $\mathrm{S}$ were raised in goats or rabbits using standard procedures. Rabbit anti-C4b-binding protein antiserum was from $\mathrm{Cal}$ biochem-Behring Corp. (San Diego, CA). BSA, soybean trypsin inhibitor, diisopropylfluorophosphate, phenylmethanesulfonylfluoride, human $\alpha$-thrombin $(3417 \mathrm{U} / \mathrm{ml})$, hirudin and Echis carinatus venom (Ecarin) were obtained from Sigma Chemical Co. (St. Louis, MO). Al other reagents were of the highest grade available.

Proteins. Human Factor VIII was purified from commercial concentrates of two different origins (see Materials). The procedure was essentially the same for both preparations and has been described elsewhere (23). The resulting Factor VIII had a specific activity of $8,000 \mathrm{U} / \mathrm{mg}$ and could be activated fivefold with thrombin $(0.05$ $\mathrm{U} / \mathrm{ml})$. It was stored at $-20^{\circ} \mathrm{C}$ in Michaelis buffer $(28.5 \mathrm{mM}$ sodium acetate, $28.5 \mathrm{mM}$ sodium barbital, $116 \mathrm{mM} \mathrm{NaCl}$, pH 7.35) containing $2 \mathrm{mM} \mathrm{CaCl}$ and $3 \mathrm{mg} / \mathrm{ml} \mathrm{BSA} \mathrm{(fatty} \mathrm{acid} \mathrm{free,} \mathrm{treated} \mathrm{with} 1 \mathrm{mM}$ diisopropylfluorophosphate and $1 \mathrm{mM}$ iodoacetic acid). Radioiodination of Factor VIII was carried out with the lactoperoxidase/glucose oxidase method (29). Factor VIII activity was determined using a onestage clotting assay $(30,31)$ or the Coatest Factor VIII chromogenic assay (Kabi). $1 \mathrm{U}$ of Factor VIII or von Willebrand factor is defined as the amount present in $1 \mathrm{ml}$ of a fresh frozen citrate plasma pool from 40 healthy donors.

von Willebrand factor was obtained during the Factor VIII purification from material eluting from the dextran sulfate-Sepharose column at high $\mathrm{CaCl}_{2}$ concentration (23) followed by dialysis against Michaelis buffer containing $1 \mathrm{mM}$ benzamidine- $\mathrm{HCl}$. After subsequent dialysis against $1.6 \mathrm{M}$ ammonium sulfate, $\mathrm{pH} 7.0$, the precipitate was dissolved in Michaelis buffer $(1.5 \mathrm{ml})$ containing $1 \mathrm{mM}$ benzamidine- $\mathrm{HCl}$ and applied to a Sephadex G-75 column $(2.6 \times 25 \mathrm{~cm})$ equilibrated in the same buffer, to remove soybean trypsin inhibitor and hirudin. von Willebrand factor antigen (VWF:Ag) was measured by ELISA technique as described (23). The specific activity of the preparation was $100 \mathrm{VWF}: \mathrm{Ag} \mathrm{U} / \mathrm{mg}$.

Factor VIII-von Willebrand factor complex was prepared by mixing purified Factor VIII (5 U) with von Willebrand factor (17 U VWF:Ag) followed by removing $\mathrm{CaCl}_{2}$ by spinning the mixture through a Centricon 30 microconcentrator and reconstituting the complex in Michaelis buffer containing $3 \mathrm{mg} / \mathrm{ml} \mathrm{BSA}$ (fatty acid free).

Protein C, protein S, and prothrombin were purified from a human plasma concentrate containing the vitamin $\mathrm{K}$-dependent proteins. Throughout the procedure, the proteins were measured by rocket immunoelectrophoresis (32). 20 bottles of concentrate were dissolved in $400 \mathrm{ml} 0.1 \mathrm{M}$ trisodium citrate, $25 \mathrm{mM}$ benzamidine- $\mathrm{HCl}, \mathrm{pH} 8.0$. After the addition of $40 \mathrm{mg}$ of soybean trypsin inhibitor, this was incubated for $30 \mathrm{~min}$ at $37^{\circ} \mathrm{C}$. All following steps (except FPLC) were performed at $4^{\circ} \mathrm{C}$. A barium citrate precipitate was obtained by slowly adding $80 \mathrm{ml}$ of $1 \mathrm{M} \mathrm{BaCl}_{2}$. The precipitate was washed with $0.1 \mathrm{M}$ $\mathrm{BaCl}_{2}, 25 \mathrm{mM}$ benzamidine- $\mathrm{HCl}, \mathrm{pH} 8.0$, and with $25 \mathrm{mM}$ benzamidine- $\mathrm{HCl}$, respectively, followed by differential precipitation with $33-70 \%$ (vol/vol) saturated ammonium sulfate. The final precipitate was dissolved and subjected to ion-exchange chromatography on a QAE-Sephadex column $(5 \times 20 \mathrm{~cm})$, equilibrated with MES-buffer $(10$ mM MES, $150 \mathrm{mM} \mathrm{NaCl}, 10 \mathrm{mM}$ EDTA, $0.02 \%$ sodium azide, $\mathrm{pH}$ 6.0). After washing with starting buffer, the proteins were eluted with a linear gradient of $\mathrm{NaCl}(0.15$ to $0.5 \mathrm{M}$ in MES buffer, $1,200 \mathrm{ml}$ in each chamber). Protein $\mathrm{C}$ and protein $\mathrm{S}$ eluted just ahead of prothrombin, which constituted the majority of protein. Prothrombin was further purified by affinity chromatography on heparin-Sepharose as described earlier (33). The QAE-Sephadex fractions containing protein C and protein $\mathrm{S}$ were pooled, concentrated threefold in a dialysis bag using Sephadex G-200 and dialyzed. Further purification of protein C and protein $\mathrm{S}$ was achieved by consecutive chromatography on Blue Sepharose CL-6B $(2.5 \times 19 \mathrm{~cm}$ in $50 \mathrm{mM}$ Tris- $\mathrm{HCl}, 150 \mathrm{mM} \mathrm{NaCl}, 2$ mM EDTA, $0.02 \%$ sodium azide, $\mathrm{pH} 7.4$ ) and heparin-Sepharose CL-6B $\left(2.5 \times 7 \mathrm{~cm}\right.$ in $50 \mathrm{mM}$ Imidazol, $50 \mathrm{mM} \mathrm{NaCl}, 2.5 \mathrm{mM} \mathrm{CaCl}_{2}$, $2 \mathrm{mM}$ benzamidine- $\mathrm{HCl}, 0.02 \%$ sodium azide, $\mathrm{pH}$ 6.0). Protein $\mathrm{C}$ and protein $\mathrm{S}$ were recovered as two overlapping peaks from the Blue Sepharose column. Protein S did not bind to the Blue Sepharose column, while protein $C$ was slightly retarded. Remaining prothrombin bound to this column. Heparin-Sepharose chromatography resulted in complete separation of protein $C$ and protein $S$. Protein $S$ had no affinity to the heparin-Sepharose column, while protein $C$ was eluted during extensive washing with starting buffer. In some cases, traces of contaminants were removed and the proteins were concentrated using mono $\mathrm{Q}$ ion-exchange FPLC in $50 \mathrm{mM}$ Tris- $\mathrm{HCl}, 150 \mathrm{mM} \mathrm{NaCl}, 2$ mM EDTA, $0.02 \%$ sodium azide, $\mathrm{pH} 7.4$ and a linear gradient of $\mathrm{NaCl}$ $(0.15$ to $0.5 \mathrm{M})$. The proteins were stored at $-70^{\circ} \mathrm{C}$ and were stable for at least 2 mo. Repeated freeze-thawing was avoided. On SDS PAGE (34), both protein $C$ and protein $S$ appeared $>95 \%$ homogeneous. Protein C showed a single band of $M_{\mathrm{r}} 62,000$ and two bands of $M_{\mathrm{r}}$ 43,000 and $M_{\mathrm{r}} 28,000$ upon reduction. Protein $\mathrm{S}$ showed a band of $M_{\mathrm{r}}$ 69,000 without reduction. Protein $C$ was activated using thrombinSepharose beads. For that purpose, prothrombin $(74 \mathrm{mg})$ was activated at $37^{\circ} \mathrm{C}$ in $10 \mathrm{ml} 0.1 \mathrm{M} \mathrm{NaHCO}_{3}, 0.5 \mathrm{M} \mathrm{NaCl}, \mathrm{pH} 8.4$, with $0.11 \mathrm{U}$ Echis carinatus venom. Thrombin activity was monitored with the chromogenic substrate $S 2238$ at a concentration of $0.2 \mathrm{mM}$ in $50 \mathrm{mM}$ Tris- $\mathrm{HCl}, 150 \mathrm{mM} \mathrm{NaCl}, 0.5 \mathrm{mg} / \mathrm{ml}$ bovine serum albumin, $\mathrm{pH} 7.8$. After maximal activation, the mixture was coupled to $7 \mathrm{~g} \mathrm{CNBr-acti-}$ vated Sepharose 4B according to the manufacturer's instructions. Concomitant coupling of the snake venom had no effect on the activity of the thrombin-Sepharose. Protein $\mathrm{C}(400 \mu \mathrm{g})$ was activated with $0.5 \mathrm{ml}$ thrombin-Sepharose in $50 \mathrm{mM}$ Tris- $\mathrm{HCl}, 150 \mathrm{mM} \mathrm{NaCl}, 2 \mathrm{mM}$ EDTA, $0.02 \%$ sodium azide, pH 7.4 at $37^{\circ} \mathrm{C}$. The activation was followed by measuring the amidolytic activity with $0.4 \mathrm{mM} \mathrm{S} 2366$ as substrate. At maximum activation the thrombin-Sepharose was spun down and washed with Tris-buffer. The supernatant and the washes were applied to a mono $Q$ column as described above to remove traces of thrombin. APC was stable for at least 2 mo when stored at $-70^{\circ} \mathrm{C}$.

Protein S and C4b-binding protein deficient plasma was prepared from plasma of a patient with severe von Willebrand's disease. For this purpose, $20 \mathrm{ml}$ of plasma was passed over two columns, containing $140 \mathrm{mg}$ anti-C4b-binding protein immunoglobulin from rabbit antiserum coupled to $10 \mathrm{~g} \mathrm{CNBr}$-activated Sepharose $4 \mathrm{~B}$ and $27 \mathrm{mg}$ of immunopurified goat anti-protein $S$ immunoglobulin coupled to $3 \mathrm{~g}$ $\mathrm{CNBr}$-activated Sepharose 4B, respectively. Rocket immunoelectrophoresis (32) showed no detectable protein $\mathrm{S}$ and $\mathrm{C} 4 \mathrm{~b}$-binding protein antigens $(<2 \%)$ in the eluate.

Factor $\mathrm{V}$ activity was determined by means of the prothrombin time in Factor V-deficient plasma.

SDS polyacrylamide slab gel electrophoresis (34) was carried out with 3-25\% gradient gels. Protein concentrations were determined colorimetrically (35) using BSA as a standard.

Inactivation of Factor VIII in a purified system. Factor VIII (final concentration $3 \mathrm{U} / \mathrm{ml}, 1.2 \mathrm{nM}$, based upon a plasma concentration of $0.1 \mu \mathrm{g} / \mathrm{ml}$ and an average molecular weight of $250,000 \mathrm{D})$ was preincubated for $5 \mathrm{~min}$ at $20^{\circ} \mathrm{C}$ with cephalin $(8 \mu \mathrm{g} / \mathrm{ml}$, treated with $1 \mathrm{mM}$ phenylmethanesulfonylfluoride) in Michaelis buffer, $\mathrm{pH} 7.35$ containing $3 \mathrm{mg} / \mathrm{ml} \mathrm{BSA}, 1 \mathrm{U} / \mathrm{ml}$ hirudin and $5 \mathrm{mM} \mathrm{CaCl}_{2}$. Then APC $(4 \mathrm{nM})$ was added together with increasing amounts of protein $S(0-240 \mathrm{nM})$ in a final volume of $110 \mu \mathrm{l} .10-\mu \mathrm{l}$ aliquots were withdrawn at different times, diluted 50-fold with ice-cold Michaelis buffer and immediately assayed for Factor VIII coagulant activity. Once diluted, the Factor VIII activity was stable for at least $30 \mathrm{~min}$.

In another set of experiments, Factor VIII-von Willebrand factor complex (containing $2 \mathrm{U} / \mathrm{ml}$ Factor VIII and $4 \mathrm{U} / \mathrm{ml} \mathrm{VWF:Ag)} \mathrm{was}$ incubated with cephalin $(8 \mu \mathrm{g} / \mathrm{ml})$, APC $(3 \mathrm{nM})$ with or without protein $\mathrm{S}(22 \mathrm{nM})$. Before the incubation, Factor VIII-von Willebrand factor complex was incubated with thrombin $(0.05 \mathrm{U} / \mathrm{ml})$ for $3 \mathrm{~min}$ at 
$20^{\circ} \mathrm{C}$. This resulted in a sevenfold activation of Factor VIII. After addition of hirudin $(1 \mathrm{U} / \mathrm{ml})$, Factor VIIIa was stable at $4^{\circ} \mathrm{C}$ for at least $2 \mathrm{~h}$. Otherwise, the conditions were as described above.

Proteolysis of Factor VIII by APC with or without protein S was investigated by substituting ${ }^{125} \mathrm{I}$-Factor $\mathrm{VIII}(0.4 \mathrm{U} / \mathrm{ml}, 0.4 \mu \mathrm{Ci} / \mathrm{ml})$ for Factor VIII. After $20 \mathrm{~min}$ of incubation at $20^{\circ} \mathrm{C}$, a $40-\mu \mathrm{l}$ aliquot was withdrawn and added to $20 \mu \mathrm{l}$ sample buffer that contained $4 \%$ (wt) vol) SDS and $10 \%$ (vol/vol) $\beta$-mercaptoethanol. The samples were boiled for $5 \mathrm{~min}$ and subjected to SDS polyacrylamide slab gel electrophoresis followed by autoradiography using Kodak X-omat AR5 film and Dupont Cronex Lightening Plus intensifying screens (DuPont Co., Wilmington, DE).

Inactivation of Factor VIII in plasma. Factor VIII $(0.15 \mathrm{U} / \mathrm{ml}$, final concentration) or Factor VIII-von Willebrand factor complex (containing $0.3 \mathrm{U} / \mathrm{ml} \mathrm{VWF}$ :Ag) were added to $100 \mu \mathrm{l}$ of either hemophilia A plasma, von Willebrand's disease plasma or von Willebrand's disease plasma immunodepleted of protein $\mathrm{S}$ and $\mathrm{C} 4 \mathrm{~b}$-binding protein (see above). Cephalin $(4 \mu \mathrm{g} / \mathrm{ml})$ and Michaelis buffer containing bovine serum albumin were added to obtain a calcium concentration of 2 $\mathrm{mM}$ and $0.5 \mathrm{U} / \mathrm{ml}$ hirudin in a final volume of $200 \mu \mathrm{l}$. After a preincubation of $5 \mathrm{~min}$ at $37^{\circ} \mathrm{C}$, APC and protein $\mathrm{S}$ were added at the indicated concentrations and at different times at $37^{\circ} \mathrm{C}, 30-\mu$ aliquots were removed, diluted 25 -fold in ice-cold buffer and remaining Factor VIII activity was measured using the Coatest chromogenic assay. The one-stage coagulation assay could not be used in these experiments, because too high dilutions of the aliquots were needed to abolish the effect of APC on the coagulation assay. In the same aliquots, the amidolytic activity of APC was measured with the chromogenic substrate S2366.

Gelfiltration of Factor VIII-von Willebrand factor complexes. Factor VIII ( 0.6 U) was mixed with various amounts of von Willebrand factor and applied to a Sepharose CL-4B column $(0.8 \times 20 \mathrm{~cm})$, which was equilibrated in Michaelis buffer containing 4\% (wt/vol) BSA and $0.005 \%$ Triton X-100. Fractions of $300 \mu \mathrm{l}$ were collected at a flow rate of $2 \mathrm{ml} / \mathrm{h}$ at $4^{\circ} \mathrm{C}$ and assayed for Factor VIII coagulant activity and von Willebrand factor antigen. The fraction containing the highest Factor VIII concentration was diluted to a final concentration of $0.6 \mathrm{U} / \mathrm{ml}$ Factor VIII and incubated with APC $(4 \mathrm{nM})$ in the presence of $4 \mu \mathrm{g} / \mathrm{ml}$ cephalin and $5 \mathrm{mM} \mathrm{CaCl}_{2}$. Factor VIII activity at different timepoints was determined as described above for the inactivation of Factor VIII in plasma.

\section{Results}

Inactivation of Factor VIII in a purified system. The inactivation of Factor VIII by APC is shown in Fig. 1. The reaction rate was dependent upon the concentration of protein S. Protein S alone, in the absence of APC, had no effect on the Factor

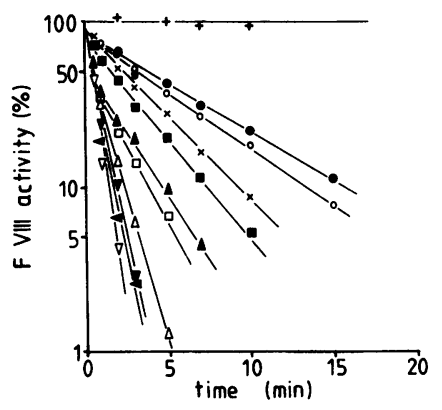

Figure 1. The effect of protein $S$ on the rate of Factor VIII inactivation. Factor VIII (3 $\mathrm{U} / \mathrm{ml}, 1.2 \mathrm{nM}$ ) in Michaelis buffer, $\mathrm{pH} 7.35$ containing BSA, hirudin, cephalin, $\mathrm{CaCl}_{2}$ (see Methods) and protein $\mathrm{S}$ at the concentrations indicated below was incubated at $20^{\circ} \mathrm{C}$ with APC (4 $\mathrm{nM})$. The residual Factor VIII activity was determined at the indicated times

with a one-stage coagulation assay as described in Methods.,+ 9.5 $\mathrm{nM}$ of protein $\mathrm{S}$ without APC; in the presence of APC, the protein $\mathrm{S}$ concentrations were: $0 \mathrm{nM}(\bullet) ; 0.5 \mathrm{nM}(0) ; 1.2 \mathrm{nM}(\times) ; 2.4 \mathrm{nM}(\bullet)$; $4.8 \mathrm{nM}(\Delta) ; 9.5 \mathrm{nM}(\square) ; 19.8 \mathrm{nM}(\Delta) ; 39.5 \mathrm{nM}(\nabla) ; 80 \mathrm{nM}(\nabla) ; 240$ $\mathrm{nM}(4)$.
VIII activity. These results demonstrate the cofactor activity of protein S on the inactivation of Factor VIII by APC. This effect was dependent on the concentration of protein $S$ (Fig. 1) and reached an approximately ninefold increase of the reaction rate. The pattern of degradation of Factor VIII in the absence or presence of protein $S$ was analyzed by SDS PAGE (Fig. 2). No differences were observed when protein $S$ was included in the reaction mixture. High molecular weight bands ranging from 90,000 to 180,000 (the Factor VIII heavy chain [23]) were degraded, while the $M_{\mathrm{r}} 80,000$ light chain band remained intact. A predominant cleavage product of $M_{\mathrm{r}}$ 43,000 was observed. Also, minor fragments of $M_{\mathrm{r}} 21,000$ and $M_{\mathrm{r}} 49,000$ were formed, the first being more prominent in the presence of protein $S$ and the latter being further degraded. Although the coagulant activity had disappeared, a small portion of the $M_{\mathrm{r}} 90,000-180,000$ bands of the radiolabeled preparation remained intact, which may be an artifact due to the labeling procedure.

The inactivation of purified Factor VIII was compared to the inactivation of the reconstituted Factor VIII-von Willebrand factor complex (Fig. 3). In the presence of von Willebrand factor, $60 \%$ of the Factor VIII activity remained after 15 min, while only $26 \%$ remained in the absence of von Willebrand factor. This clearly indicated a protection of Factor VIII by von Willebrand factor. In addition, protein S did not affect the APC-induced inactivation of the complex. Activation of the Factor VIII-von Willebrand factor complex with thrombin before the incubation with APC however, restored the suscep-

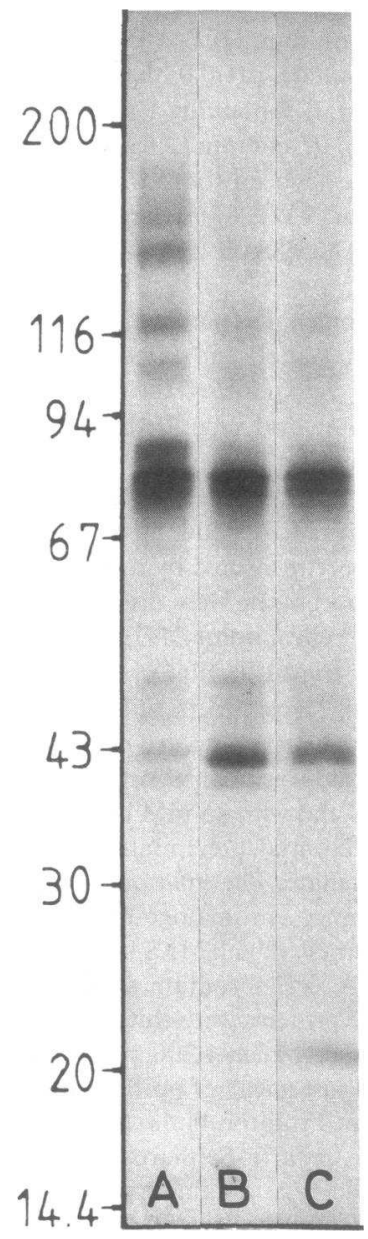

Figure 2. Proteolysis of Factor VIII by APC. ${ }^{125} \mathrm{I}$-Factor VIII $(0.4 \mathrm{U} / \mathrm{ml}$, $0.4 \mu \mathrm{Ci} / \mathrm{ml})(A)$ was incubated with APC $(4 \mathrm{nM})$ in the absence $(B)$ or presence $(C)$ of protein $\mathrm{S}(22 \mathrm{nM})$. At $20 \mathrm{~min}$, samples were removed and prepared for SDS-electrophoresis and autoradiography. For details see Methods. 


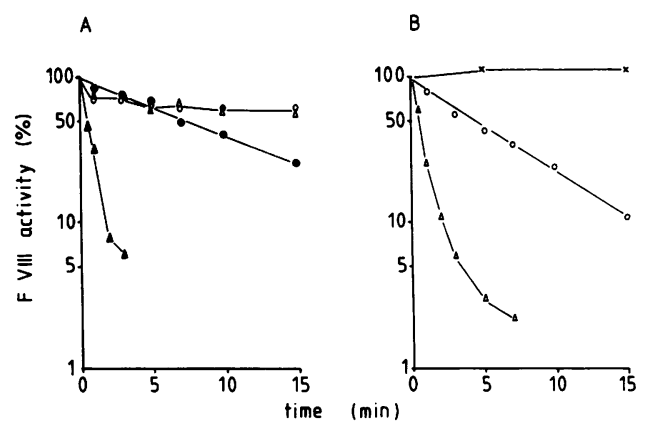

Figure 3. The effect of von Willebrand factor on Factor VIII inactivation. (A) Factor VIII $(2 \mathrm{U} / \mathrm{ml})$ (solid symbols) or Factor VIII-von Willebrand factor (containing $4 \mathrm{U} / \mathrm{ml}$ VWF:Ag) (open symbols) was incubated with $\operatorname{APC}(3 \mathrm{nM})$ in the absence $(\bullet, 0)$ or presence $(\Delta, \Delta)$ of protein $\mathrm{S}(22 \mathrm{nM})$. The conditions of incubation were as described in Methods. $(B)$ Before incubation with APC, Factor VIII-von Willebrand factor was activated with thrombin. $(x)$, control incubation without APC.

tibility of Factor VIII to APC. Addition of protein S (20 nM) then caused a 10-fold enhancement of the reaction. Thus, release of Factor VIII from von Willebrand factor by thrombin (24) eliminated the protective effect of von Willebrand factor. von Willebrand factor did not influence the amidolytic activity of APC towards the chromogenic substrate S2366 (not shown).

Inactivation of Factor VIII in plasma. To further investigate the role of von Willebrand factor, we added Factor VIII or Factor VIII-von Willebrand factor complex to either von Willebrand's disease plasma or hemophilic plasma. In von Willebrand's disease plasma, Factor VIII was readily inactivated when APC ( $5 \mathrm{nM})$ was added in the presence of cephalin and $\mathrm{CaCl}_{2}$ (Fig. $4 \mathrm{~A}$ ), resulting in a $90 \%$ inhibition of the Factor VIII activity in $15 \mathrm{~min}$. Addition of an extra amount of protein $\mathrm{S}(22 \mathrm{nM})$ to the plasma enhanced the reaction, resulting in a 95\% inhibition in $15 \mathrm{~min}$. In contrast, when Factor VIII was present as a complex with von Willebrand factor, the inactivation by APC was much slower, resulting in a $25 \%$ inhibition in

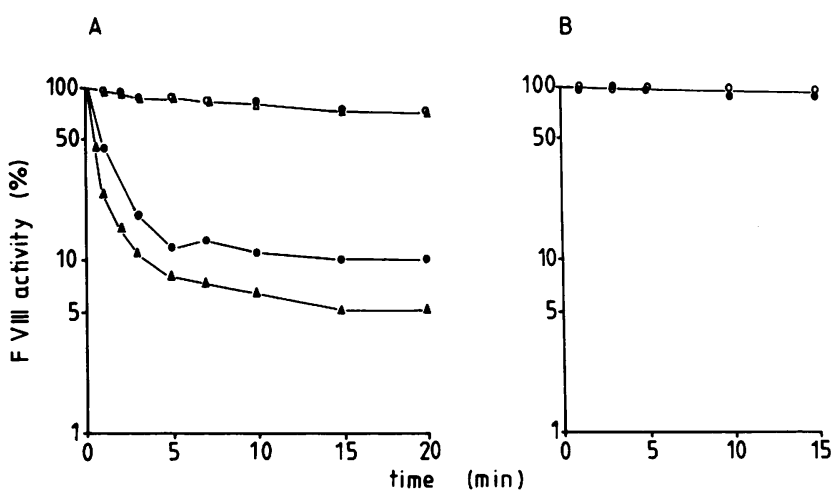

Figure 4. Inactivation of Factor VIII in plasma. $(A)$ Inactivation in von Willebrand's disease plasma. Factor VIII $(0.15 \mathrm{U} / \mathrm{ml}, \bullet)$ or Factor VIII-von Willebrand factor ( $0.3 \mathrm{U} / \mathrm{ml} \mathrm{VWF:Ag,} \mathrm{O})$ was added to the plasma together with cephalin and buffer containing $\mathrm{CaCl}_{2}$ (see Methods). After a preincubation of $5 \mathrm{~min}$ at $37^{\circ} \mathrm{C}$, APC was added $(4 \mathrm{nM})$. At the times indicated, aliquots were withdrawn and residual Factor VIII activity was measured using the Coatest VIII assay. $\Delta, \Delta$, in the presence of additional protein $S(22 \mathrm{nM})$. (B) The same experiment as in A was repeated in hemophilic plasma.
15 min. Addition of extra protein $\mathrm{S}$ had no effect on this reaction. In hemophilic plasma, which expressed an almost normal von Willebrand factor content, this protective effect was even more pronounced (Fig. 4 B). Factor VIII, which was added to the plasma 5 min before the addition of APC, maintained $89 \%$ of its activity after 15 min. Purified Factor VIII therefore seemed to associate readily with endogenous von Willebrand factor. Factor VIII, which was added to hemophilic plasma as a complex with von Willebrand factor, was not inactivated by APC. The rate of inactivation of APC as assessed by its amidolytic activity towards the chromogenic substrate S2366 was in the same range in both plasmas: after 15 min incubation at $37^{\circ} \mathrm{C}, 90 \%$ of the APC activity remained in von Willebrand's disease plasma and $80 \%$ remained in hemophilic plasma. To further assess the relevance of protein $S$ in the inactivation of Factor VIII in plasma, von Willebrand's disease plasma was immunodepleted of both protein $S$ and $\mathrm{C} 4 \mathrm{~b}$-binding protein. $\mathrm{C} 4 \mathrm{~b}$-binding protein binds approximately half of the protein $S$ present in plasma, thereby inhibiting its cofactor activity $(14,15)$. In the absence of protein $S$, APC did not inactivate Factor VIII (Fig. 5). When purified protein $\mathrm{S}$ was added back to the plasma (final concentration 22 $\mathrm{nM}$ ), the inactivation of Factor VIII was completely restored.

A mixing experiment with hemophilia $\mathrm{A}$ and von Willebrand's disease plasmas was performed to determine the amount of von Willebrand factor needed to protect Factor VIII from inactivation by APC (Fig. 6). A final concentration of $0.3 \mathrm{VWF}: \mathrm{Ag} \mathrm{U} / \mathrm{ml}$ was needed for complete protection of Factor VIII $(0.2 \mathrm{U} / \mathrm{ml})$ at an APC concentration of $16 \mathrm{nM}$, suggesting that at least a 1:1 ratio on a unit basis of von Willebrand factor to Factor VIII is needed to fully incorporate Factor VIII in a protective complex.

To assess whether Factor VIII did indeed form a complex with von Willebrand factor after reconstitution, we mixed purified von Willebrand factor with increasing amounts of purified Factor VIII and subjected the mixture to gelfiltration using Sepharose CL-4B. Factor VIII coeluted with von Willebrand factor in the void volume of the column $(4.2 \mathrm{ml})$ even when the von Willebrand factor concentration was only $18 \%$ of the Factor VIII concentration (based on units) (Table I). The recovery of Factor VIII in the void volume was $~ 85 \%$ and was not correlated to the amount of von Willebrand factor. Purified Factor VIII in the absence of von Willebrand factor eluted in the included volume $(8.1 \mathrm{ml})$ of the column with a recovery of $27 \%$. Subsequent treatment of the Factor VIII-containing fractions with APC showed that although all

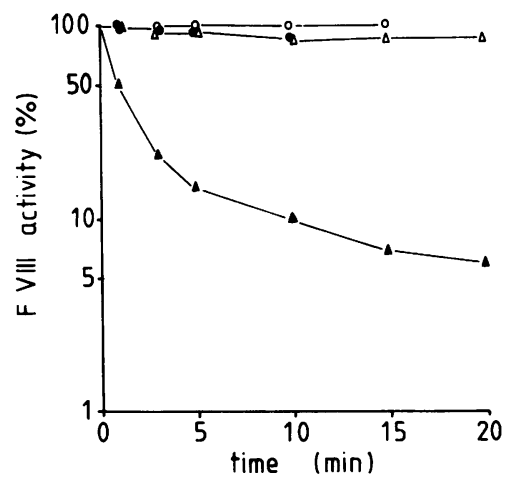

Figure 5. Inactivation of Factor VIII in von Willebrand's disease plasma depleted of protein S. APC (4 $\mathrm{nM}$ ) was added to plasma containing Factor VIII $(0.2$ $\mathrm{U} / \mathrm{ml}$, solid symbols) or Factor VIII-von Willebrand factor (open symbols) in the absence (๑, O) or presence $(\Delta, \Delta)$ of exogenous protein $\mathrm{S}(22$ nM). Further details are explained in Methods. 


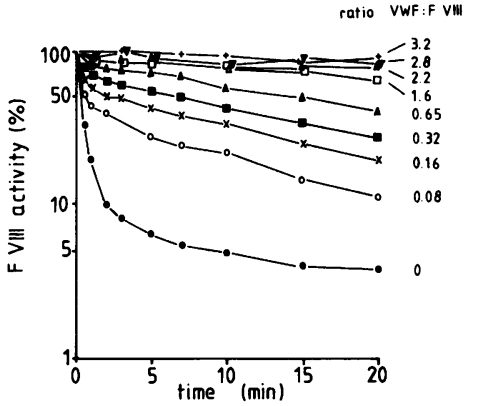

final concentration of VWF:Ag $(\mathrm{U} / \mathrm{ml})$ in the mixture was: $0(\bullet)$; $0.015(0) ; 0.03(\times) ; 0.06(\Delta) ; 0.13(\Delta) ; 0.31(\square) ; 0.44(\Delta) ; 0.56(\nabla) ; 0.63$ $(+)$.

Factor VIII may be bound to von Willebrand factor, this does not provide maximal protection against APC. For example, only $32 \%$ of the Factor VIII activity remained after $10 \mathrm{~min}$ treatment with APC when Factor VIII was present in a 5.6-fold excess over von Willebrand factor. In the presence of a 3.7-fold excess of von Willebrand factor, $89 \%$ of the Factor VIII activity was retained (Table I).

To investigate whether full multimerization of von Willebrand factor is a prerequisite for protection of Factor VIII, we added APC to various plasmas of five patients with type IIA von Willebrand's disease. The results (Table II) demonstrate that if the VWF:Ag to Factor VIII ratio is more than one (on the basis of units), there is little inactivation of Factor VIII. Therefore, high and low molecular weight forms of von Willebrand factor seem to be equally potent in protecting Factor VIII against proteolysis by APC. When the Factor VIII concentration in the plasma of one patient (E.) was increased by adding purified Factor VIII, the same percentage of activity $(80 \%)$ remained after 20 min of incubation with APC, indicating that endogenous and exogenous Factor VIII are equally well protected.

Since Factor V is also a substrate for APC, we wished to demonstrate that the protective effect of von Willebrand factor is specific for Factor VIII. For this purpose, plasma from a patient with severe von Willebrand's disease, which contained $72 \%$ of the normal Factor $V$ concentration, was incubated with APC (30 nM). Fig. 7 shows that the inactivation of Factor $V$ in plasma was not influenced by the addition of von Willebrand factor $(14 \mathrm{U} / \mathrm{ml})$.

\section{Discussion}

The studies presented in this report have focussed on two aspects of the inactivation of Factor VIII by activated protein

Table I. Inactivation of Factor VIII-von Willebrand Factor Complexes after Gel Filtration

\begin{tabular}{ccccc}
\hline FVIII & VWF:Ag & VWF/FVIII & Elution* & FVIII after 10 APC \\
\hline$U / m l$ & $U / m l$ & $U / U$ & & $\%$ \\
0.12 & 0.00 & 0 & I & 30 \\
0.39 & 0.07 & 0.18 & V & 32 \\
0.58 & 0.22 & 0.38 & V & 52 \\
0.35 & 1.3 & 3.7 & V & 89 \\
\hline
\end{tabular}

* I, included volume $(8.1 \mathrm{ml})$; $\mathrm{V}$, void volume $(4.2 \mathrm{ml})$.
Table II. Inactivation of Factor VIII in Variant Type IIA von Willebrand's Disease Plasma

\begin{tabular}{lcccc}
\hline Plasma source & VWF:Ag & VWF:RiCof* & FVIII & FVIII after 20' APC \\
\hline & $U / m l$ & $U / m l$ & $U / m l$ & $\%$ \\
VWD type IIA & & & & \\
A & 0.27 & 0.07 & 0.20 & 79 \\
B & 0.37 & 0.07 & 0.30 & 89 \\
C & 0.54 & ND & 0.20 & 80 \\
D & 0.68 & 0.13 & 0.20 & 67 \\
E & 0.42 & 0.14 & 0.21 & 84 \\
& & & $0.38^{\ddagger}$ & 84 \\
VWD type III & 0 & 0 & $0.46^{\ddagger}$ & 1 \\
Hemophilia A & 0.65 & ND & $0.34^{\ddagger}$ & 90 \\
& & & & \\
\hline
\end{tabular}

* RiCof, ristocetin cofactor activity (30).

¥ Purified Factor VIII has been added to obtain the final concentration mentioned.

C. First, we have shown that protein $\mathbf{S}$ serves as a cofactor for APC in this reaction. This is in agreement with previous observations $(22,36)$ and analogous with the inactivation of Factor V by APC. Second, a protective effect of von Willebrand was demonstrated against the action of APC.

The reaction rate of Factor VIII inactivation was enhanced ninefold in the presence of protein $S$. The same effect was seen when thrombin-activated Factor VIII was used (results not shown). Similarly, Walker (13) observed a fivefold increase of the Factor Va inactivation by APC. The importance of protein $S$ as an anticoagulant protein has been inferred from the inability of APC to prolong the clotting time of protein S-deficient plasma $(15,37)$ and from the high risk of thrombosis that results from a protein S deficiency $(15,38-40)$. Although APC can inactivate purified Factor VIII in the absence of protein $S$ (Figs. 1, 2, and 3 [5-7]), we found no inactivation of Factor VIII in von Willebrand's disease plasma from which protein $S$ was removed (Fig. 5). Moreover, addition of extra protein $S$ to plasma which expressed a normal protein $\mathrm{S}$ content, enhanced the effect of APC (Fig. $4 \mathrm{~A}$ ). During the incubation, the concentration of plasma-derived, free protein $S$ (i.e., not complexed to C4b-binding protein) would have been $\sim 66 \mathrm{nM}$ (41), which is a 16-fold excess over the amount of APC that we added to this plasma. Moreover, comparison of Figs. 1 and $4 A$ shows that in plasma the reaction rate decreases during the incubation, although only $10 \%$ of the APC activity was lost. It seems that APC and protein S function less efficiently in plasma than in a purified system, perhaps because the pro-

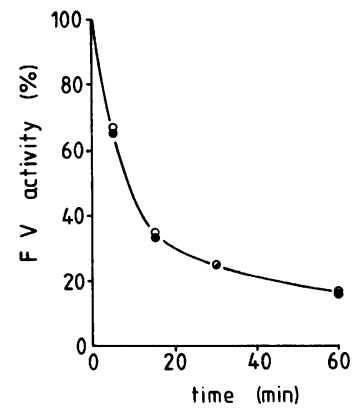

Figure 7. Inactivation of Factor $\mathrm{V}$ by APC. von Willebrand's disease plasma was incubated with APC ( 30 $\mathrm{nM}$ ) in the presence of cephalin and calcium. Remaining Factor V activity was determined at various timepoints and expressed as percentage of initial activity. (๑), no von Willebrand factor present; (o), in the presence of 14 $\mathrm{U} / \mathrm{ml}$ von Willebrand factor. 
tein S-APC-phospholipid complex (13) is partly bound to Factor V.

Analysis of ${ }^{125}$ I-Factor VIII degradation by APC on SDS polyacrylamide gels showed essentially the same pattern as observed before $(6,7)$. While the $M_{\mathrm{r}} 80,000$ light chain was unaffected, the $M_{\mathrm{r}} 90,000-180,000$ heavy chain polypeptides disappeared with a concomitant production of $M_{\mathrm{r}} 49,000$, 43,000 , and 21,000 fragments. No qualitative differences were observed when protein $S$ was included in the reaction mixture, indicating that protein $\mathrm{S}$ accelerates the inactivation of Factor VIII without changing the specificity of APC for the cleavage site on the heavy chain of Factor VIII (7). Recently, Walker et al. (22) described the proteolysis of Factor VIII by APC and protein $\mathrm{S}$. They also found no new polypeptides upon addition of protein S. Final cleavage products of $M_{\mathrm{r}} 48,000$ and 23,000 were observed, which are equivalent to our $M_{\mathrm{r}} 43,000$ and 21,000 bands. A transient band of $M_{\mathrm{r}} 53,000$ is probably identical to our $M_{\mathrm{r}} 49,000$ band, although we have not established that this product is derived from a different segment of the Factor VIII molecule than the $M_{\mathrm{r}} 90,000$ aminoterminal heavy chain fragment (22). We did not observe the $M_{\mathrm{r}} 68,000$ fragment described by Walker et al.

In plasma, Factor VIII circulates in a complex with von Willebrand factor. We found that in the presence of von Willebrand factor, Factor VIII is protected against APC. This effect is specific for Factor VIII, since the inactivation of Factor $\mathrm{V}$ in plasma was not affected by von Willebrand factor (Fig. 7). Although Factor VIII binds to von Willebrand factor through its carboxy-terminal light chain (42), and APC inactivates Factor VIII by proteolytic cleavage of the amino-terminal heavy chain, it cannot be excluded that von Willebrand factor shields off the cleavage site for APC, or alternatively, induces a conformational change in the Factor VIII molecule that makes the cleavage site less accessible. Another possible explanation is derived from analogies with Factor Va. Like Factor VIII, Factor Va is inactivated by APC by cleavage of the heavy chain in the presence of phospholipids $(3,43)$. The light chain, which contains the binding site of Factor $\mathrm{Va}$ for phospholipids (44) is needed for this reaction (3). Accordingly, von Willebrand factor could prevent the formation of a Factor VIII-phospholipid-APC complex by inhibiting the binding of Factor VIII to phospholipids. A competition between von Willebrand factor and phospholipids for Factor VIII has been demonstrated (45, 46), and we have observed a diminished binding of factor VIII-light chain to von Willebrand factor in the presence of phospholipids (Hamer, R., and J. Koedam, unpublished observation). Recently, the light chain of Factor VIII was reported to contain the phospholipid binding site (47). It is also noteworthy that the inactivation of the Factor VIII-von Willebrand factor complex by APC is not influenced by protein $\mathrm{S}$ (Figs. 3, $4 \mathrm{~A}$, and 5). Possibly, the binding of the protein S-APC-phospholipid complex to Factor VIII is inhibited by von Willebrand factor. Studies to further characterize these interactions are in progress.

By varying the amount of von Willebrand factor in plasma in the presence of constant amounts of Factor VIII and APC, we have shown that a one to one ratio of von Willebrand factor to Factor VIII (based on units) is needed in order to obtain full protection. von Willebrand factor exists in plasma as a series of multimers $(48,49)$ composed of a subunit of $M_{\mathrm{r}} 270,000$. In normal plasma, this subunit is present in an $\sim 100$-fold molar excess over Factor VIII (assuming an $M_{\mathrm{r}}$ of 270,000 for Factor VIII and concentrations of 10 and $0.1 \mu \mathrm{g} / \mathrm{ml}$ for von Willebrand factor and Factor VIII, respectively). Multimers of high molecular weight as well as of low molecular weight have been shown to express coagulant activity and thus bind Factor VIII $(50,51)$. We used gel filtration to demonstrate binding of Factor VIII to von Willebrand factor. As much as $5.6 \mathrm{U}$ of Factor VIII eluted with $1 \mathrm{U}$ of von Willebrand factor in the void volume of the column (Table II). Similarly, Zucker et al. (52) have shown that von Willebrand factor in plasma can be loaded with at least 12 times the amount of Factor VIII that is normally present. In spite of this excess of apparent binding sites on von Willebrand factor for Factor VIII, there exists a close correlation between the concentrations of the two proteins in normals and in many disease states $(53,54)$. The study of Weiss et al. (26) demonstrated an increased lability of Factor VIII especially in those plasmas which expressed a Factor VIII/von Willebrand factor ratio of more than one. These observations support our finding that although $1 \mathrm{U}$ of von Willebrand factor may bind more than one unit Factor VIII, a 1:1 ratio as found in normal plasma is needed for full protection against proteolysis (Fig. 6, Table II). The mechanism underlying this apparent discrepancy between binding and protection of Factor VIII by von Willebrand factor is under current investigation. The normal resistance of Factor VIII to APC in patients with type IIA von Willebrand's disease (Table II) is in favor of a quantitative rather than a qualitative (i.e., high degree of multimerization) requirement of von Willebrand factor for protection of Factor VIII.

In conclusion, our results suggest that APC may function locally at sites where Factor VIII has been activated, but is not responsible for the catabolism of Factor VIII that circulates in a complex with von Willebrand factor.

\section{Acknowledgments}

The technical help of Nel H. Beeser-Visser and Riek A. A. Vlooswijk is gratefully acknowledged.

This project was supported by grant TSN 86-016 from the Netherlands Thrombosis Foundation.

\section{References}

1. Esmon, C. T. 1987. The regulation of natural anticoagulant pathways. Science (Wash. DC). 235:1348-1352.

2. Kisiel, W., W. M. Canfield, L. H. Ericsson, and E. W. Davie. 1977. Anticoagulant properties of bovine plasma protein $\mathrm{C}$ following activation by thrombin. Biochemistry. 16:5824-5831.

3. Suzuki, K., J. Stenflo, B. Dahlbäck, and B. Theodorsson. 1983. Inactivation of human coagulation factor $\mathrm{V}$ by activated protein $\mathrm{C} . J$. Biol. Chem. 258:1914-1920.

4. Vehar, G. A., and E. W. Davie. 1980. Preparation and properties of bovine factor VIII (anti-hemophilic factor). Biochemistry. 19:401410.

5. Marlar, R. A., A. J. Kleiss, and J. H. Griffin. 1982. Mechanism of action of human activated protein $\mathrm{C}$, a thrombin-dependent anticoagulant enzyme. Blood. 59:1067-1072.

6. Fulcher, C. A., J. E. Gardiner, J. H. Griffin, and T. S. Zimmerman. 1984. Proteolytic inactivation of human factor VIII procoagulant protein by activated human protein $\mathrm{C}$ and its analogy with factor $\mathrm{V}$. Blood. 63:486-489.

7. Eaton, D., H. Rodriguez, and G. A. Vehar. 1986. Proteolytic 
processing of human factor VIII. Correlation of specific cleavages by thrombin, factor $\mathrm{Xa}$, and activated protein $\mathrm{C}$ with activation and inactivation of factor VIII coagulant activity. Biochemistry. 25:505-512.

8. Comp, P. C., and C. T. Esmon. 1981. Generation of fibrinolytic activity by infusion of activated protein $\mathrm{C}$ into dogs. J. Clin. Invest. 68:1221-1228.

9. Van Hinsbergh, V. W. M., R. M. Bertina, A. van Wijngaarden, N. H. van Tilburg, J. J. Emeis, and F. Haverkate. 1985. Activated protein $\mathrm{C}$ decreases plasminogen activator-inhibitor activity in endothelial cell-conditioned medium. Blood. 65:444-451.

10. Esmon, C. T., and W. G. Owen. 1981. Identification of an endothelial cell cofactor for thrombin-catalyzed activation of protein C. Proc. Natl. Acad. Sci. USA. 78:2249-2252.

11. Esmon, N. L., W. G. Owen, and C. T. Esmon. 1982. Isolation of a membrane-bound cofactor for thrombin-catalyzed activation of protein C. J. Biol. Chem. 257:859-864.

12. Salem, H. H., G. J. Broze, J. P. Miletich, and P. W. Majerus, 1983. Human coagulation factor $\mathrm{Va}$ is a cofactor for the activation of protein C. Proc. Natl. Acad. Sci. USA. 80:1584-1588.

13. Walker, F. J. 1981. Regulation of activated protein C by protein S. The role of phospholipid in factor Va inactivation. J. Biol. Chem. 256:11128-11131.

14. Dahlbäck, B., and J. Stenflo. 1981. High molecular weight complex in human plasma between vitamin K-dependent protein $\mathrm{S}$ and complement component $\mathrm{C} 4 \mathrm{~b}$-binding protein. Proc. Natl. Acad. Sci. USA. 78:2512-2516.

15. Comp, P. C., R. R. Nixon, M. R. Cooper, and C. T. Esmon. 1984. Familial protein $S$ deficiency is associated with recurrent thrombosis. J. Clin. Invest. 74:2082-2088.

16. Suzuki, K., J. Nishioka, and S. Hashimoto. 1983. Protein C inhibitor. Purification from human plasma and characterization. $J$. Biol. Chem. 258:163-168.

17. Harris, K. W., and C. T. Esmon. 1985. Protein $S$ is required for bovine platelets to support activated protein $\mathrm{C}$ binding and activity. $J$. Biol. Chem. 260:2007-2010.

18. Stern, D. M., P. P. Nawroth, K. Harris, and C. T. Esmon. 1986. Cultured bovine endothelial cells promote activated protein C-protein S-mediated inactivation of factor Va. J. Biol. Chem. 261:713-718.

19. Walker, F. J., P. W. Sexton, and C. T. Esmon. 1979. The inhibition of blood coagulation by activated protein $\mathrm{C}$ through the selective inactivation of activated factor V. Biochim. Biophys. Acta $571: 333-342$.

20. Nesheim, M. E., W. M. Canfield, W. Kisiel, and K. G. Mann. 1982. Studies of the capacity of factor Xa to protect factor Va from inactivation by activated protein C. J. Biol. Chem. 257:1443-1447.

21. Bertina, R. M., R. Cupers, and A. van Wijngaarden. 1984. Factor IXa protects activated factor VIII against inactivation by activated protein C. Biochem. Biophys. Res. Commun. 125:177-183.

22. Walker; F. J., S. I. Chavin, and P. J. Fay. 1987. Inactivation of factor VIII by activated protein C and protein S. Arch. Biochem. Biophys. 252:322-328.

23. Hamer, R. J., J. A. Koedam, N. H. Beeser-Visser, and J. J. Sixma. 1986. Human factor VIII: purification from commercial factor VIII concentrate, characterization, identification and radiolabeling. Biochim. Biophys. Acta. 873:356-366.

24. Hamer, R. J., J. A. Koedam, N. H. Beeser-Visser, and J. J. Sixma. 1987. The effect of thrombin on the complex between factor VIII and von Willebrand factor. Eur. J. Biochem. 167:253-259.

25. Sakariassen, K. S., P. A. Bolhuis, and J. J. Sixma. 1979. Human blood platelet adhesion to artery subendothelium is mediated by factor VIII-von Willebrand factor bound to the subendothelium. Nature (Lond.). 279:636-638.

26. Weiss, H. J., I. I. Sussman, and L. W. Hoyer. 1977. Stabilization of factor VIII in plasma by the von Willebrand factor. Studies on posttransfusion and dissociated factor VIII and in patients with von Willebrand's disease. J. Clin. Invest. 60:390-404.

27. Allain, J. P., H. A. Cooper, R. H. Wagner, and K. M. Brink- hous. 1975. Platelets fixed with paraformaldehyde: a new reagent for assay of von Willebrand factor and platelet aggregating factor. J. Lab. Clin. Med. 85:318-328.

28. Ruggeri, Z. M., and T. S. Zimmerman. 1980. Variant von Willebrand's disease: characterization of two subtypes by analysis of multimeric composition of factor VIII-von Willebrand factor in plasma and platelets. J. Clin. Invest. 65:1318-1325.

29. Davis, G. S., and R. A. Reisfeld. 1974. Protein iodination with solid state lactoperoxidase. Biochemistry. 13:1014-1021.

30. Veltkamp, J. J., E. F. Drion, and E. A. Loeliger. 1968. Detection of the carrier state in hereditary coagulation disorders. I. Thromb. Diath. Haemorrh. 19:279-303.

31. Bouma, B. N. and A. E. Starkenburg. 1974. Dilution of haemophilic plasma used as a reagent in the determination of anti-haemophilic factor A (factor VIII). Haemostasis. 3:94-97.

32. Laurell, C. B. 1966. Quantitative estimation of proteins by electrophoresis in agarose gels containing antibodies. Anal. Biochem. 15:45-52.

33. Fujikawa, K., A. R. Thompson, M. E. Legaz, R. G. Meyer, and E. W. Davie. 1973. Isolation and characterization of bovine factor IX (Christmas factor). Biochemistry. 12:4938-4945.

34. Laemmli, U. K. 1970. Cleavage of structural proteins during the assembly of the head of bacteriophage T4. Nature (Lond.). 227:680-685.

35. Lowry, O. H., N. J. Rosebrough, A. L. Farr, and R. J. Randall. 1951. Protein measurement with the Folin phenol reagent. J. Biol. Chem. 193:265-275.

36. Lawrence, J. E., M. A. Batard, C. W. Berridge, and C. A. Fulcher. 1985. Protein S enhances the inactivation of factor VIII by activated protein C. Thromb. Haemostasis. 54:83. (Abstr.)

37. Walker, F. J. 1980. Regulation of activated protein C by a new protein. A possible function for bovine protein S. J. Biol. Chem. 255:5521-5524.

38. Comp, P. C., and C. T. Esmon. 1984. Recurrent venous thromboembolism in patients with a partial deficiency of protein S. $N$. Engl. J. Med. 311:1525-1528.

39. Schwarz, H. P., M. Fischer, P. Hopmeier, M. A. Batard, and J. H. Griffin. 1984. Plasma protein S deficiency in familial thrombotic disease. Blood. 64:1297-1300.

40. Broekmans, A. W., R. M. Bertina, J. Reinalda-Poot, L. Engesser, H. P. Muller, J. A. Leeuw, J. J. Michiels, E. J. P. Brommer, and E. Briet. 1985. Hereditary protein $S$ deficiency and venous thromboembolism. A study in three Dutch families. Thromb. Haemostasis. 53:273-277.

41. Dahlbäck, B. 1983. Purification of human vitamin K-dependent protein $\mathrm{S}$ and its limited proteolysis by thrombin. Biochem. $J$. 209:837-846.

42. Hamer, R. J., J. A. Koedam, N. H. Beeser-Visser, R. M. Bertina, J. A. van Mourik, and J. J. Sixma. 1987. Factor VIII binds to von Willebrand factor via its Mr 80000 light chain. Eur. J. Biochem. 166:37-43.

43. Van de Waart, P., H. Bruls, H. C. Hemker, and T. Lindhout. 1984. Functional properties of factor Va subunits after proteolytic alterations by activated protein C. Biochim. Biophys. Acta. 799:38-44.

44. Van de Waart, P., H. Bruls, H. C. Hemker, and T. Lindhout. 1983. Interaction of bovine blood clotting factor $\mathrm{Va}$ and its subunits with phospholipid vesicles. Biochemistry. 22:2427-2432.

45. Andersson, L.-O., and J. E. Brown. 1981. Interaction of factor VIII-von Willebrand factor with phospholipid vesicles. Biochem. $J$. 200:161-167.

46. Lajmanovich, A., G. Hudry-Clergeon, J.-M. Freyssinet, and G. Marguerie. 1981. Human factor VIII procoagulant activity and phospholipid interaction. Biochim. Biophys. Acta. 678:132-136.

47. Kemball-Cook, G., S. J. Edwards, K. Sewerin, L.-O. Andersson, and T. W. Barrowcliffe. 1987. The phospholipid-binding site of factor VIII is located on the $80 \mathrm{kD}$ light chain. Thromb. Haemostasis. 58:222. (Abstr.) 
48. Van Mourik, J. A., B. N. Bouma, W. T. LaBruyere, S. de Graaf, and I. A. Mochtar. 1974. Factor VIII, a series of homologous oligomers and a complex of two proteins. Thromb. Res. 4:155-164.

49. Fass, D. N., G. J. Knutson, and E. J. W. Bowie. 1978. Porcine von Willebrand factor: a population of multimers. J. Lab. Clin. Med. 91:307-320.

50. Over, J., B. N. Bouma, J. J. Sixma, P. A. Bolhuis, and R. A. A. Vlooswijk. 1980. Heterogeneity of factor VIII. II. Transitions between forms of factor VIII present in cryoprecipitate and in cryosupernatant plasma. J. Lab. Clin. Med. 95:323-334.

51. Perret, B. A., M. Furlan, F. Knuebuehl, and E. A. Beck. 1981.
Fractionation of individual, biologically active factor VIII multimers. Biochim. Biophys. Acta 669:98-104.

52. Zucker, M. B., M. E. Soberano, A. J. Johnson, A. J. Fulton, S. Kowalski, and M. Adler. 1983. The in vitro association of antihemophilic factor and von Willebrand factor. Thromb. Haemostasis. 49:37-41.

53. Hoyer, L. W. 1972. Immunologic studies of antihemophilic factor (AHF, factor VIII). IV. Radioimmunoassay of AHF antigen. $J$. Lab. Clin. Med. 80:822-833.

54. Rizza, C. R., I. L. Rhymes, D. E. G. Austen, P. B. A. Kernoff, and S. A. Aroni. 1975. Detection of carriers of haemophilia: a "blind" study. Br. J. Haematol. 30:447-457. 